\title{
EFFECTS OF BUTTER ON BLOOD BIOCHEMISTRY AND HISTOTEXURE OF HEART IN THE DEVELOPMENT OF OBESITY IN SWISS ALBINO MICE
}

\author{
M. S. Islam ${ }^{2 *}$, M. K. Islam ${ }^{1}$, S. K. Das ${ }^{3}$, M. M. Hossain ${ }^{4}$ \\ ${ }^{1}$ Department of Physiology, Bangladesh Agricultural University, Mymensingh-2202 \\ ${ }^{2}$ School of Agriculture and Rural Development, Bangladesh Open University, Gazipur-1705 \\ ${ }^{3}$ Department of Anatomy and Histology, Bangladesh Agricultural University, Mymensingh-2202 \\ ${ }^{4}$ Department of Anatomy, Histology and Physiology, Sher-e-Bangla agricultural University, Sher-e- Bangla \\ Nagar, Dhaka-1207
}

\begin{abstract}
The study was designed and performed in order to investigate the effects of butter on blood biochemistry and histo-texture of heart in mice. Thirty days old 30 Swiss Albino mice were divided into 3 equal groups $\left(M, M_{1}\right.$, and $\left.M_{2}\right)$. Mice of group $M$ were fed with normal mice pellet and were designated as control. Mice in the group $\mathrm{M}_{1}$ and $\mathrm{M}_{2}$ were fed with $10 \%$ and $20 \%$ butter supplemented feed respectively. In biochemical study, group $\mathrm{M}_{2}$ showed increase in total plasma cholesterol $(\mathrm{P}<0.001)$, LDL $(\mathrm{P}<0.001)$, TG $(\mathrm{P}<0.001)$, blood glucose $(\mathrm{P}<0.05)$, blood urea nitrogen $(\mathrm{P}<0.05)$ compared to mice in control group. In group of $\mathrm{M}_{1}$ there were also increase in total plasma cholesterol ( $\left.\mathrm{P}<0.01\right)$, LDL $(\mathrm{P}<0.001)$, TG $(\mathrm{P}<0.001)$, blood glucose $(\mathrm{P}<0.05)$, blood urea nitrogen $(\mathrm{P}<0.05)$ compared to mice in control group but lesser increased than the mice fed with $20 \%$ butter supplemented feed. In histopathological study there was no significant change in the heart of mice.
\end{abstract}

Key words: Mice, Obesity, Butter, Hypercholesterolemia, Hypocholesterolemia

\section{INTRODUCTION}

Obesity is a medical condition in which excess body fat is accumulated to the extent that it may have an adverse effect on health, leading to reduced life expectancy and/or increased health problems. A person is obese when Body Mass Index (BMI) is greater than $30 \mathrm{~kg} / \mathrm{m}^{2}$ (WHO, 2000). Obesity is a major health problem worldwide. In United States, roughly 300,000 deaths per year are related to obesity. Obesity also increases the risk of developing several chronic diseases such as type 2 diabetes, insulin resistance, coronary heart disease (responsible for heart attacks), cerebrovascular disease (responsible for strokes), high blood pressure, gout, gallstones, colon cancer, sleep apnea, and a form of liver disease called nonalcoholic fatty liver disease (NAFLD) (Haslam and James, 2005). Clinical and epidemiological studies have led to the identification of the genetic, environmental, and inflammatory risk factors of these diseases like dyslipidemia, hypertension, diabetes, obesity, smoking, high-fat diet, fatty liver disease, and chronic inflammation (Glass and Witztum, 2001). According to the National Health health care systems and Nutrition Examination Survey (NHANES), between 1999 and 2010 the overall age-adjusted prevalence of obesity in the USA was $35.8 \%$ in adult men and 35.5\% in adult women (Flegal et al., 2010). It is now well established that obesity is an independent risk factor for the development of cardiovascular diseases. Cardiovascular disease (CVD) is a degenerative disease that most often occurs and becomes a major killer in industrialized countries. In developing countries, the incidence of cardiovascular disease is increasing alarmingly (Okrainec et al., 2004). CVD is emerging as a serious health hazard in Bangladesh. Latest survey on cardiovascular diseases in Bangladesh showed prevalence of ischemic or coronary heart disease (CHD) in adult population about 10\% (National Heart Foundation of Bangladesh, 2010).

A major cardiovascular disease of the productive age is coronary heart disease (CHD), which is closely related to atherosclerosis (Kalim et al., 1996). Compared to men, women suffer a disproportionate burden of disease attributable to overweight and obesity. Female obesity is defined as an excessive amount of body fat, keeping in mind the Body Mass Index ratio, of the woman concerned. The body mass index (BMI), is the most popular and effective way of calculating female Obesity. The occurrence of CVD can be reduced by decreasing the formation of atherosclerosis through lowering cholesterol levels in the blood and increasing the concentration of high density lipoprotein (Nogrady, 1992). Generally, high-fat diets, high sucrose/fructose diets, diets high in saturated fats and restricted in certain essential nutrients, like choline and methionine, have been shown to cause obesity and fatty

*Corresponding e-mail address: k_islam88@yahoo.co.in 


\section{S. Islam and others}

livers in a number of different strains and species of rodents (Koteish, 2011). High-fat/high-cholesterol western diets induce extreme hypercholesterolemia and also lead to concomitant features of the metabolic syndrome, such as weight gain, decreased HDL levels, obesity, hypertriglyceridemia, hyperinsulinemia, and insulin resistance (Hartvigsen et al., 2007; Li et al., 2000). In addition, these diets generate pathologies independent of atherosclerosis, such as changes in fur and skin integrity, changes in plasma lipids, and hepatic steatosis (Lichtman et al., 1999; Gajda et al., 2007). This suggests that "overnutrition" might play a role in the genesis of obesity related fatty liver disease and other risk factors associated with metabolic syndrome (Gajda et al., 2007). Dietary cholesterol has been shown to reduce fatty acid oxidation, which in turn increases the levels of hepatic and plasma triacylglycerols (TG) (Fungwe et al., 1993). Evidences from lipid lowering trials have clearly established that reduction of total cholesterol or low density lipoprotein cholesterol (LDL-C) is associated with decreased risk of atherosclerosis and CHD (Brown et al., 1998; Grundy et al., 2005). The ingestion of polyunsaturated fatty acids present in vegetable oils is inversely related to the incidence of heart diseases by decreasing the cholesterol and triacylglycerol plasmatic levels. Increased adiposity and insulin resistance contribute to the progression from NASH to fibrosis through the development of a profibrotic milieu in the liver, including increased hepatocellular death (Chiang et al., 2011). Commercial butter is about $80 \%$ butter fat and $15 \%$ water; traditionally made butter may have as little as $65 \%$ fat and $30 \%$ water containing high proportion of saturated fat. Saturated fat consists of triglycerides containing only saturated fatty acids having no double bonds between the individual carbon atoms of the fatty acid chain. That is, the chain of carbon atoms is fully "saturated" with hydrogen atoms (Jakobsen et al., 2009). Chemically butterfat consists essentially of a mixture of triglycerides, particularly those derived from fatty acids, such as palmitic, oleic, myristic, and stearic acids. Fats rich in saturated fatty acids can result in the elevation of plasma total and lipoprotein cholesterol (Yuan et al., 1998). Changes in the diet in terms of fatty acid content can have a marked effect on lipid profile of blood. Therefore, the investigation was made by the application of high fat to learn about any alteration in biochemical blood profile of and in histo-texture of heart in mice.

\section{MATERIALS AND METHODS}

The experiment was conducted in the Department of Physiology, Bangladesh Agricultural University, Mymensingh during a period of 3 months from 25 September through 25 December 2013.

\section{Animals}

One month old 30 Swiss Albino mice with an average body weight of 15-18 gm were purchased from ICDDR, Bangladesh, Mohakhali, Dhaka. Before being used in the experiment, mice were adapted for 7 days in order to acclimatize in the environment. All groups were housed in a compartmentalized rectangular metallic cages $(9 \times$ $11 \times 7$ cubic inches) wrapped with wire mesh. The cages were kept in well ventilated room at $28 \pm 2^{\circ} \mathrm{C}$ and a relative humidity of $70-80 \%$ with natural day and light.

\section{Experimental design}

The mice were randomly divided into 3 equal groups $\left(M, M_{1}\right.$ and $\left.M_{2}\right)$. Each group consisted of 10 mice $(n=10)$. Group $\mathrm{M}$ was kept as control and animals were fed with normal broiler pellet (HI-PRO-VITE feed; $5 \mathrm{gm} /$ mice/day). Mice of group $\mathrm{M}_{1}$ and $\mathrm{M}_{1}$ were fed with $10 \%$ and $20 \%$ butter with feed, respectively. Butter was collected from local KR market of Bangladesh Agricultural University (BAU), Mymensingh. All groups were supplied with standard broiler pellet (HI-PRO-VITE feed; $5 \mathrm{gm} / \mathrm{mice} /$ day) and fresh drinking water was given ad libitum throughout the experimental period of 90 days.

\section{Collection of samples}

On the $1^{\text {st }}$ day (after acclimation) from the tail and at the end of the experiment, blood sample was collected by sacrificing the mice. Sera samples were separated and stored at $-20^{\circ} \mathrm{C}$ temperature until being used. On the $90^{\text {th }}$ day of the experiment, heart from the experimental mice were collected by sacrificing in $10 \%$ buffered formalin and used for histopathological study.

\section{Biochemical studies}

The biochemical parameters of serum like Total Cholesterol, Triglyceride, HDL, LDL, Blood glucose, Billurubin, Blood urea nitrogen, serum creatinine, ALT, AST, were estimated. 


\section{Determination of total serum cholesterol and triglycerides}

The cholesterol was determined using the procedure described by Trinder (1969). The result was expressed in $\mathrm{mg} / \mathrm{dl}$.

The triglyceride of blood serum was determined by Biochemistry Humalyzer-3000 (Human type, Germany) according to the technique described by Trinder (1969). The result was expressed in mg/dl.

\section{Determination of HDL and LDL cholesterol}

The concentration of serum HDL cholesterol was estimated with the incubation of supernatant of serum sample and reagent mixture in Reflectron ${ }^{\circledR}$ Humalyzer 3000 (Human type, Germany) and then placing the mixture in the Reflection ${ }^{\circledR}$ against the blank reagent. The result was expressed in $\mathrm{mg} / \mathrm{dl}$. The LDL was determined by subtracting the HDL cholesterol value from the subtracted value of triglyceride from total serum cholesterol that was divided by five.

$$
\text { LDL LDL-C }=\frac{\text { Total serum Cholesterol }- \text { Triglycerides }}{5}-\text { HDL-C }
$$

\section{Determination of blood glucose}

The Blood glucose was determined after enzymatic hydrolysis with amylases. The blood glucose was determined by Biochemistry Humalyzer-3000 (Human type, Germany) according to GOD TAT method. The result was expressed in $\mathrm{mg} / \mathrm{dl}$.

\section{Determination of AST \& ALT}

AST and ALT values were recorded through placing the mixture of serum sample and test reagent (enzyme/coenzyme/ $\alpha$ - oxoglutarate AL 1205) in the Humalyzer 2000. The AST value was calculated as: AST/ALT Concen. $=1746 \times$ absorbance U/L.

\section{Determination of Bilirubin and Blood Urea Nitrogen}

Bilirubin estimation was performed according to the method described by Peterson et al. (1952). The result was expressed in $\mathrm{mg} / \mathrm{dl}$. Blood urea nitrogen was determined applying the Modified Berthelot Methodology and expressed as $\mathrm{gm} / \mathrm{dl}$.

\section{Histopathological study}

Histopathological examination was performed in the Department of Anatomy and Histology, BAU, Mymensingh. Fixed tissue sections were processed; paraffin-embedded and sectioned were routinely stained with Hematoxylin and Eosin (H \& E) stain as per standard procedure.

\section{Statistical analyses}

All data were expressed as mean $\pm \mathrm{SD}$, and differences among the groups of animals were compared using one-way ANOVA with post-hoc Duncans test. Paired t- tests were used to compare pre-treatment and posttreatment value of different groups. Statistical significance was set at $P<0.05$. Statistical analysis was performed using SPSS software version 17 (SPSS Inc., Chicago, IL, USA).

\section{RESULTS AND DISCUSSION}

In the present study the result shows that effects of various percentages of butter on blood biochemistry vary significantly. In case of blood sugar both percentages (10\% and 20\%) of butter supplemented feed signifies the result at $(\mathrm{P}<0.05)$ compared to control group that is in agreement with the study of Hoefel et al. (2011) who reported that in liver, glycogen synthesis and concentration were higher in rats receiving hypercaloric saturated fat (HSF) and normocaloric saturated fat (NSF). The significant result of TG $(\mathrm{P}<0.001)$ in the present study could be compared with the study of Bałasińska and Mazur (2004) who reported that dietary lipids participate actively in the development of atherosclerosis which is characterized by elevated triglyceride levels in blood plasma. Again the significant result of TC $(\mathrm{P}<0.001)$ and LDL $(\mathrm{P}<0.01)$ in this study is similar with the study of Ohlsson (2010) who reported that the saturated fatty acids increase total plasma cholesterol, especially LDL-C. In case of 


\section{S. Islam and others}

blood urea nitrogen and serum creatinine result is significant at $(\mathrm{P}<0.05)$ level that could be compared with the study of Jing Lu et al. (2003) who showed that high fat diet causes detrimental effect on kidney, causing renal inflammation and fibrosis resulting low clearance of creatinine and increase in blood urea nitrogen. In the histopathological section of heart, there was no significant changes among control group, $10 \%$ butter treated and, (c) 20\% butter treated groups (Fig. A, B and C). The present research findings help in drawing a conclusion that $20 \%$ butter supplementation would be able to cause changes in biochemical parameters of blood.

Table 1. Effects of various percentages of butter on blood sugar, bilirubin, TC, TG, HDL and LDL, in Swiss albino mice

\begin{tabular}{|c|c|c|c|c|}
\hline Parameters & Groups & Pre treatment & Post Treatment & $\begin{array}{l}\text { Level of } \\
\text { Significance }\end{array}$ \\
\hline \multirow{3}{*}{$\begin{array}{l}\text { Blood Sugar } \\
(\mathrm{mg} / \mathrm{dl})\end{array}$} & $\mathrm{M}$ (Control) & $45.00 \pm 1.35$ & $48.26 \pm 1.05^{\mathrm{b}}$ & NS \\
\hline & $\mathrm{M}_{1}(10 \%$ butter $)$ & $44.00 \pm 1.43$ & $95.13 \pm 1.64^{\mathrm{a}}$ & $*$ \\
\hline & $\mathrm{M}_{2}(20 \%$ butter $)$ & $43.50 \pm 1.90$ & $102.92 \pm 1.14^{\mathrm{a}}$ & $*$ \\
\hline \multirow{3}{*}{ Bilirubin (mg/dl) } & $\mathrm{M}$ (Control) & $0.20 \pm 0.01$ & $0.19 \pm 0.02^{\mathrm{b}}$ & NS \\
\hline & $\mathrm{M}_{1}(10 \%$ butter $)$ & $0.19 \pm 0.02$ & $0.20 \pm 0.02^{\mathrm{b}}$ & NS \\
\hline & $\mathrm{M}_{2}(20 \%$ butter $)$ & $0.18 \pm 0.02$ & $0.19 \pm 0.06^{\mathrm{b}}$ & NS \\
\hline \multirow{3}{*}{$\mathrm{TC}(\mathrm{mg} / \mathrm{dl})$} & $\mathrm{M}$ (Control) & $45.00 \pm 1.10$ & $48.74 \pm 1.20^{\mathrm{c}}$ & NS \\
\hline & $\mathrm{M}_{1}(10 \%$ butter $)$ & $44.23 \pm 1.01$ & $84.52 \pm 1.38^{\mathrm{a}}$ & $* *$ \\
\hline & $\mathrm{M}_{2}(20 \%$ butter $)$ & $44.90 \pm 1.00$ & $132.38 \pm 1.89^{\mathrm{a}}$ & $* * *$ \\
\hline \multirow{3}{*}{ TG (mg/dl) } & M (Control) & $46.32 \pm 1.00$ & $53.60 \pm 0.75^{\mathrm{c}}$ & NS \\
\hline & $\mathrm{M}_{1}(10 \%$ butter $)$ & $45.56 \pm 0.70$ & $103.70 \pm 0.65^{\mathrm{a}}$ & $* * *$ \\
\hline & $\mathrm{M}_{2}$ (20\% butter) & $45.43 \pm 0.71$ & $139.04 \pm 1.56^{\mathrm{a}}$ & $* * *$ \\
\hline \multirow{3}{*}{$\mathrm{HDL}(\mathrm{mg} / \mathrm{dl})$} & $\mathrm{M}$ (Control) & $18.50 \pm 1.09$ & $20.05 \pm 1.04^{\mathrm{b}}$ & NS \\
\hline & $\mathrm{M}_{1}(10 \%$ butter $)$ & $18.00 \pm 1.10$ & $19.10 \pm 1.14^{\mathrm{b}}$ & NS \\
\hline & $\mathrm{M}_{2}(20 \%$ butter $)$ & $17.87 \pm 1.08$ & $19.00 \pm 1.23^{\mathrm{c}}$ & NS \\
\hline \multirow{3}{*}{$\mathrm{LDL}(\mathrm{mg} / \mathrm{dl})$} & M (Control) & $26.23 \pm 1.30$ & $29.37 \pm 1.74^{\mathrm{c}}$ & NS \\
\hline & $\mathrm{M}_{1}(10 \%$ butter $)$ & $25.00 \pm 2.15$ & $95.71 \pm 1.78^{\mathrm{a}}$ & $* * *$ \\
\hline & $\mathrm{M}_{2}(20 \%$ butter $)$ & $25.58 \pm 2.50$ & $97.42 \pm 3.43^{\mathrm{a}}$ & $* * *$ \\
\hline
\end{tabular}


Effects of butter on blood biochemistry in swiss albino mice

Table 2. Effects of various percentages of butter on AST, ALT, and BUN in Swiss albino mice

\begin{tabular}{|lllll|}
\hline Parameters & Groups & Pre treatment & Post Treatment & $\begin{array}{l}\text { Level of } \\
\text { Significance }\end{array}$ \\
\hline \multirow{3}{*}{ AST (U/L) } & $\mathrm{M}$ (Control) & $40.12 \pm 0.23$ & $41.82 \pm 2.48^{\mathrm{c}}$ & $\mathrm{NS}$ \\
& $\mathrm{M}_{1}(10 \%$ butter $)$ & $41.23 \pm 0.43$ & $41.90 \pm 2.08$ & $\mathrm{NS}$ \\
& $\mathrm{M}_{2}(20 \%$ butter $)$ & $41.56 \pm 0.53$ & $42.67 \pm 3.06^{\mathrm{b}}$ & $\mathrm{NS}$ \\
& $\mathrm{M}$ (Control) & $22.35 \pm 1.78$ & $22.67 \pm 1.55^{\mathrm{c}}$ & $\mathrm{NS}$ \\
ALT (U/L) & $\mathrm{M}_{1}(10 \%$ butter $)$ & $23.21 \pm 1.10$ & $24.00 \pm 2.00^{\mathrm{b}}$ & $\mathrm{NS}$ \\
& $\mathrm{M}_{2}(20 \%$ butter $)$ & $22.48 \pm 1.03$ & $23.00 \pm 2.00^{\mathrm{b}}$ & $\mathrm{NS}$ \\
& $\mathrm{M}($ Control $)$ & $25.00 \pm 1.35$ & $25.46 \pm 1.18^{\mathrm{b}}$ & $\mathrm{NS}$ \\
BUN (gm/dl) & $\mathrm{M}_{1}(10 \%$ butter $)$ & $25.01 \pm 1.45$ & $31.97 \pm 1.63^{\mathrm{b}}$ & $*$ \\
& $\mathrm{M}_{2}(20 \%$ butter $)$ & $26.07 \pm 1.35$ & $32.92 \pm 0.74^{\mathrm{b}}$ & $*$ \\
\hline
\end{tabular}

The present study is a preliminary work on laboratory animal in this area. The study is in limitation due to the period of time, percentage of butter supplementation, environmental facilities, no. of animals used and so on. Hence there remains an intension to perform the study in detail in future with the overcome of the present impediments that would be able to get a rigid and confirm idea about obesity and its related complications in mammals and that could be used as a model for human.
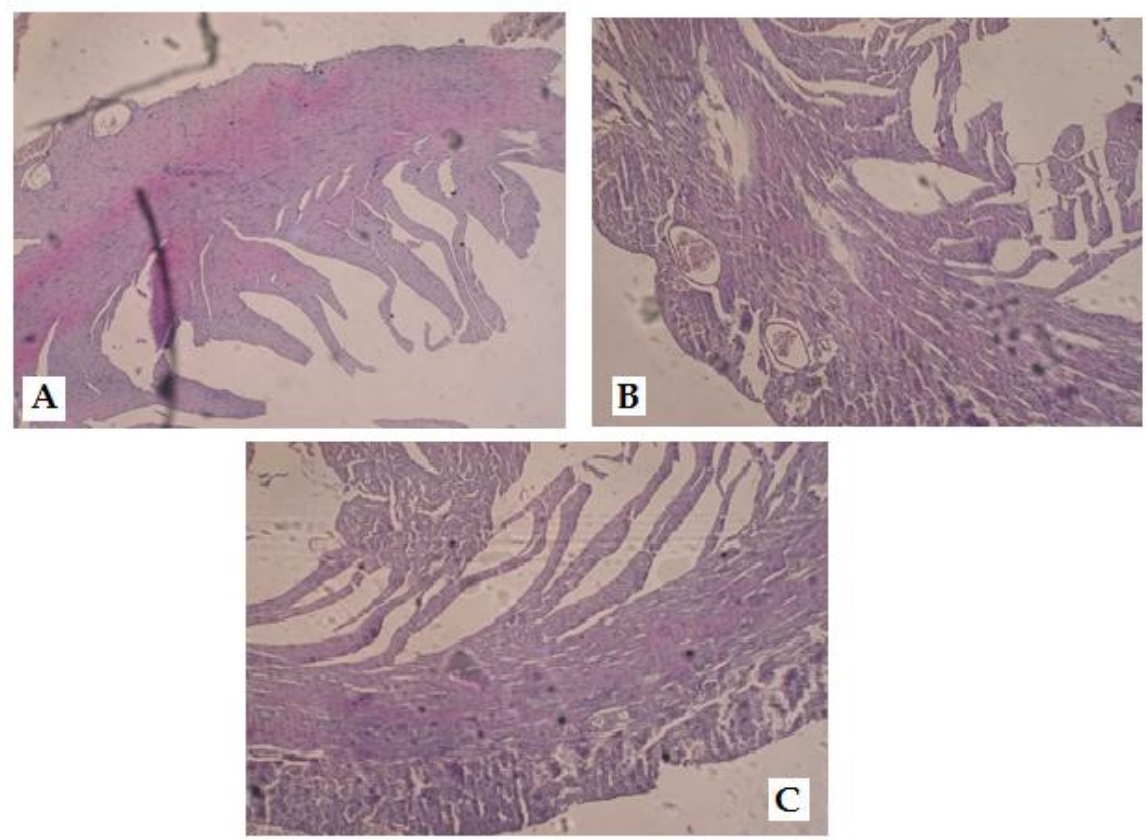

Fig. 1. Histopathological lesions: A. Control group, B. 10\% Butter treated group, and C. $20 \%$ butter treated group. 


\section{S. Islam and others}

\section{REFERENCES}

1. Aguilar-Salinas CA, Garcia EG, Robles L, Riano D, Ruiz-Gomez DG, Garcia-Ulloa AC, Melgarejo MA, Zamora M, Guillen-Pineda LE, Mehta R, Canizales-Quinteros S, Tusie Luna MT and Gomez-Perez FJ (2008). High adiponectin concentrations are associated with the metabolically healthy obese phenotype. The Journal Clinical Endocrinology and Metabolism 10: 4075-90.

2. Bałasińska B and Mazur A (2004). Oxidized dietary lipids may participate in the development of atherosclerosis. Postepy Higieny i Medycyny Doswiadczalnej (Online) 58: 176-82.

3. Braun N, Wade NS, Wakeland EK and Major AS (2008). Accelerated atherosclerosis is independent of feeding high fat diet in systemic lupus erythematosus-susceptible LDLr(-/-) mice. Lupus 17: 1070-1078.

4. Brown AS, Bakker ARG and Yellen L (1998). Treating patients with documented atherosclerosis to National Cholesterol Education Program - recommended low density lipoprotein cholesterol goals with atorvastatin, fluvastatin, lovastatin and simvastatin. Journal of Molecular Cell and Cardiology 32: 665-92.

5. Cha S, Yu H and Kim JY (2012). Bone mineral density-associated polymorphisms are associated with obesityrelated traits in Korean adults in a sex-dependent manner. PLos One 7: e53013.

6. Chen W, Wilson JL, Khaksari M, Cowley MA and Enriori PJ (2012). Abdominal fat analyzed by DEXA scan reflects visceral body fat and improves the phenotype description and the assessment of metabolic risk in mice. American Journal of Physiology, Endocrinology and Metabolism 03: 635-643.

7. Chiang DJ, Pritchard MT and Nagy LE (2011). Obesity, diabetes mellitus, and liver fibrosis. Gastrointestinal and Liver Physiology 300: 697-702.

8. Corona G, Rastrelli G, Monami M, Saad F, Luconi M, Lucchese M, Facchiano E, Sforza A, Forti G, Mannucci E and Maggi M (2013). Body weight loss reverts obesity-associated hypogonadotropic hypogonadism: a systematic review and meta-analysis. European Journal of Endocrinology 168: 829-843.

9. De Angelis G and Chen Y (2013). Obesity among women may increase the risk of arthritis: observations from the Canadian Community Health Survey, 2007-2008. Rheumatology International [Epub ahead of print].

10. Eder K, Keller U and Brandsch C (20040. Effects of a dietary oxidized fat on cholesterol in plasma and lipoproteins and the susceptibility of low-density lipoproteins to lipid peroxidation in guinea pigs fed diets with different concentrations of vitamins E and C. International Journal for Vitamin and Nutrition Research 74: 1120.

11. Farah CS and Salome CM (2012). Asthma and obesity: a known association but unknown mechanism. Respirology (Cartlon, Vic) 17: 412-421.

12. Flegal KM, Carroll MD, Ogden CL and Curtin LR (2010). Prevalence and trends in obesity among US adults, 1999-2008. The Journal of the American Medical Association 303: 235-241.

13. Fuhrman B and Aviram M (2001). Anti-atherogenicity of nutritional antioxidants. The Investigational Drugs Journal 4: 82-92.

14. Fungwe TV, Cagen LM, Cook GA, Wilcox HG and Heimberg M (1993). Dietary cholesterol stimulates hepatic biosynthesis of triglyceride and reduces oxidation of fatty acids in the rat. Journal of Lipid Research 34: 933-941.

15. Gajda A, Pellizzon M, Ricci M and Ullman E (2007). Diet-induced metabolic syndrome in rodent models. Animal Laboratory News 365: 1415-1428.

16. Gallant AR, Tremblay A, Perusse L, Despres JP, Bouchard C and Drapeau V (2013). Parental eating behavior traits are related to offspring BMI in the Québec Family Study. International Journal of Obesity [Epub ahead of print].

17. Ganji SH, Kamanna VS and Kashyap ML (2003). Niacin and cholesterol: role in cardiovascular disease (review). The Journal of Nutritional Biochemistry 14: 298-305.

18. Gennest J and Libby P (2011). Lipoprotein disorders and cardiovascular disease. In: Bonow RO, Mann DL, Zipes DP, and Libby P, eds. Braunwald's Heart Disease: A Textbook of Cardiovascular Medicine. $9^{\text {th }}$ edn Philadelphia, Pa: Saunders Elsevier; chap 47.

19. Glass CK and Witztum JL (2010). Atherosclerosis, the road ahead. Cell 104: 503-516.

20. Gribovskaja-Rupp I, Kosinski L and Ludwig KA (2011). Obesity and colorectal cancer. Clinics in Colon and Rectal Surgery 24: 229-243.

21. Grundy SM, Cleeman JI and Daniels SR (2005). Diagnosis and management of the metabolic syndrome - An American Heart Association/National Heart, Lung, and Blood Institute Scientific Statement. Circulation 112: $2735-2752$.

22. Grundy SM, Cleeman JI and Merz CN (2004). Implications of recent clinical trials for the National Cholesterol Education Program Adult Panel on Detection, Evaluation and Treatment of high blood cholesterol in adults. Journal of the American Medical Association 285: 2486-2497. 
23. Hartvigsen K, Binder CJ and Hansen LF (2007). A diet-induced hypercholesterolemic murine model to study atherogenesis without obesity and metabolic syndrome. Arteriosclerosis, Thrombosis and Vascular Biology 27: 878-85.

24. Haslam DW and James WP (2005). Obesity. Lancet 366: 1197-209.

25. Hoefel AL, Hansen F, Rosa PD, Assis AM, Silveira SL, Denardin CC, Pettenuzzo L, Augusti PR, Somacal S, Emanuelli T, Perry ML and Wannmacher CM (2011). The effects of hypercaloric diets on glucose homeostasis in the rat: influence of saturated and monounsaturated dietary lipids. Cell Biochemistry and Function 29: 569-76.

26. Ishibashi S, Goldstein JL, Brown MS, Herz J and Burns DK (1990). Massive xanthomatosis and atherosclerosis in cholesterol-fed low density lipoprotein receptor-negative mice. Journal of Lipid Research 31: 859-869.

27. Jakobsen MU, O'Reilly EJ, Heitmann BL, Pereira MA, Bälter K, Fraser GE, Goldbourt U and Hallmans G (2009). Major types of dietary fat and risk of coronary heart disease: a pooled analysis of 11 cohort studies. The American Journal of Clinical Nutrition 89: 1425-1432.

28. Jing Lu, Bankovic-Calic N, Ogborn M, Saboorian MH and Aukema HM (2003). Detrimental Effects of a High Fat Diet in Early Renal Injury are ameliorated by Fish Oil in Han:SPRD-cy Rats. Journal of Nutrition 133: 180-186.

29. Khan-Merchant N, Penumetcha M, Meilhac O and Parthasarathy S (2002). Oxidized fatty acids promote atherosclerosis only in the presence of dietary cholesterol in low-density lipoprotein receptor knockout mice. The Journal of Nutrition 132: 3256-3262.

30. Kohn MJ, Bell JF, Grow HM and Chan G (2013). Food insecurity, food assistance and weight status in US youth: new evidence from NHANES 2007-08. Pediatric Obesity [Epub ahead of print].

31. Koteish A and Diehl AM (2001). Animal models of steatosis. Seminars in Liver Disease 28: 89-104.

32. Lichtman AH, Clinton SK, Iiyama K, Connelly PW, Libby P and Cybulsky MI (1999). Hyperlipidemia and atherosclerotic lesion development in LDL receptor deficient mice fed defined semipurified diets with and without cholate. Arteriosclerosis, Thrombosis and Vascular Biology 19: 1938-1944.

33. Lin ECK, Fernandez ML and McNamara DJ (1992). Dietary fat type and cholesterol quantity interact to affect cholesterol metabolism in guinea pigs. The Journal of Nutrition 122: 2019-2029.

34. Nogrady T (1992). Medicinal chemistry: a biochemical approach. Penerbit ITB, Bandung, [Indonesia].

35. Ohlsson L (2010). Dairy products and plasma cholesterol levels. Food and Nutrition Research 54: 10.

36. Okrainec K, Banerjee DK and Eisenberg MJ (2004). Coronary artery disease in the developing world. American Journal of Heart 148: 7-15. 